\title{
KEPUASAN WISATAWAN TERHADAP ELEMEN DAYA TARIK WISATA PANTAI KUTA LOMBOK
}

\author{
Yuni Sulpia Hariani \\ Prodi Magister Pariwisata Universitas Udayana \\ Email: yunisulpiahariani@gmail.com \\ I Gusti Ayu Oka Suryawardani \\ Universitas Udayana \\ Email: gungdani@gmail.com \\ I Ketut Surya Diarta \\ Universitas Udayana \\ Email: suryadiarta@unud.ac.id
}

\begin{abstract}
Tourism development can be seen from two strategic development approaches, one of them is the aspect of market driven. This research is aimed 1) To identify the factors that influence the tourists' satisfaction who have visited the Kuta Beach Lombok; 2) To analyze the relationship between tourists' importance level and performance of tourism destination elements of Kuta Beach Lombok; 3) To determine the development priority based on tourists' satisfaction on the performance of tourism destination elements of Kuta Beach Lombok. This research is based on quantitative method that are factor analysis and Important Performance Analysis. Sample determination in this research used purposive sampling. The number of sampel for factor analysis is 165 and 30 samples for Important Performance analysis of foreign tourists' who have visited Kuta Beach Lombok. Data in this research were gathered by questionnaire. Factor analysis showed eight factors that affected the tourists' satisfaction who have visited Kuta Beach Lombok that are accomodation, hospitality, transportation, public facilities, infrastructure, tourism facility, safety and price. Importance Performance analysis showed the suitability level of importance and performance of tourism destination elements of Kuta Beach Lombok have satisfied the foreign tourists. The development strategy is increasing the bad performance of tourism destination elements in quandran I and maintaining the good performance of tourism destination elements in quandran II based on the result of caretesian quandrant.
\end{abstract}

Keywords: development, tourism destination, tourists' satisfaction 


\section{Pendahuluan}

Salah satu destinasi wisata di Provinsi NTB yang menawarkan ragam Daya Tarik Wisata ialah Pulau Lombok. Sebagai destinasi wisata, Pulau Lombok ditunjang oleh bauran elemen destinasi wisata. Elemen-elemen destinasi wisata tersebut seperti ragam atraksi wisata, fasilitas pariwisata, infrastruktur, transportasi, dan keramahtamahan. Tujuan dari elemen-elemen destinasi wisata tersebut tentunya untuk memuaskan pengalaman berwisata kepada wisatawan (Mill dan Morrison, 2009). Untuk itu, pengembangan pada sektor pariwisata terus dilakukan di Pulau Lombok yang bertujuan untuk menyediakan keperluan wisatawan selama berkunjung. Salah satu upaya pembangunan yang dilakukan untuk menunjang kegiatan pariwisata di Pulau Lombok ialah pengembangan salah satu Bali baru (Saufi dkk, 2015).

KEK Mandalika ini merupakan salah satu dari sepuluh Bali Baru dan merupakan Kawasan Strategis Pariwisata Nasional. Kawasan Ekonomi Khusus Mandalika ini juga termasuk ke dalam Kawasan Strategis Pariwisata Daerah sesuai dengan yang tertuang dalam PP nomor 7 daerah Provinsi NTB pada tahun 2013 pasal 13 mengenai rencana induk pembangunan kepariwisataan 2013-2028 di daerah.

Pantai Kuta Lombok terletak di dalam KEK Mandalika yang sekarang sedang diprioritaskan untuk dibangun. Pengembangan Pantai Kuta di Lombok ini sudah direncanakan semenjak 26 tahun lalu (Suara NTB, 2017), akan tetapi karena adanya permasalahan persengketaan lahan membuat pengembangan menjadi terhambat. Permasalahan mengenai sengketa lahan ini akhirnya bisa diselesaikan dengan dikeluarkannya instruksi presiden (Suara NTB, 2017).

Pengembangan secara intensif di Pantai Kuta Lombok baru mulai dilakukan semenjak penetapan KEK Mandalika dalam PP negara Republik Indonesia nomor 52 di tahun 2014. Pengembangan di Daya Tarik Wisata Pantai Kuta Lombok ditandai 
dengan pembangunan fasilitas wisata berupa akomodasi seperti berbagai hotel seperti Hotel Pullman dengan 251 kamar, Hotel Royal Tulip dengan 250 kamar, Hotel X2 dengan 200 kamar, dan Hotel paramount denga 400 kamar (Beritagar, 2018). Selain itu, informasi yang didapat dari hasil observasi yaitu adanya perbaikan infrastruktur jalan, pembangunan bala wisata yang berfungsi sebagai pusat informasi, penyediaan fasilitas bermian untuk anak, pembangunan pusat perbelanjaan modern, dan pembangunan tempat ibadah.

Keindahan atraksi Pantai Kuta Lombok dengan berbagai elemen pendukung pariwisata pada kenyataannya belum memberikan kepuasan yang maksimal kepada wisatawan yang berkunjung. Ketidakpuasan wisatawan ini dapat dilihat dengan adanya keluhan beberapa wisatawan yang dibagikan pada situs berbagi informasi Tripadvisor. Keluhan yang dinyatakan oleh bsejumlah wisatawan seperti pembuatan jalan yang sangat dekat dengan garis pantai, kurang terjaganya kebersihan di area pantai serta pembangunan masif yang dilakukan pemerintah terutama mengenai bangunan multi fungsi yang dibangun tepat di pinggir pantai (Tripadvisor, 2018).

Wang (2016) menyatakan bahwa pengalaman berwisata yang tidak memuaskan wisatawan dapat memberi pengaruh yang kurang baik seperti cerita buruk mengenai destinasi yang sudah dikunjungi, beralih ke destinasi wisata lain, mengurangi daya saing dan kesempatan berkembang untuk destinasi wisata itu sendiri. Pendapat dari Corte dkk (2015) juga menyatakan bahwa pengalaman positif yang didapat wisatawan terkait pelayanan produk wisata dan sumber daya lainnya di destinasi wisata akan bisa membentuk ingatan wisatawan seperti bercerita hal positif dari mulut ke mulut. Selain dua pendapat di atas, Pizam dkk (dalam Aktas dkk, 2009) menyatakan bahwa kepuasan atau ketidakpuasan wisatawan terhadap salah satu elemen destinasi wisata bisa berpengaruh terhadap kepuasan atau ketidakpuasan dengan produk pariwisata secara keseluruhan. 
Memastikan kepuasan wisatawan merupakan hal yang sangat penting untuk kesuksesan jangka panjang dari sebuah destinasi wisata dan membawa manfaat bagi stakeholder, termasuk industri, wisatawan, dan juga masyarakat lokal (Wang, 2016). Terdapat beberapa keuntungan yang didapat oleh destinasi wisata dengan memuaskan wisatawan seperti pembelian ulang, bersedia membayar lebih, setia pada destinasi wisata, cerita positif dari mulut ke mulut, berbelanja di satu tempat dan inovasi produk wisata (Sheth dalam Wang, 2016).

Melihat betapa pentingnya kepuasan wisatawan terhadap destinasi wisata dan implikasinya serta adanya keluhan wistawan terhadap beberapa aspek di Daya Tarik Wisata Pantai Kuta Lombok sebagaimana yang sudah diuraikan sebelumnya, maka dirasa sangat penting untuk menganalisis tingkat kepuasan wisatawan yang berkunjung ke sana. Analisis kepuasan wisatawan tersebut penting agar diperoleh informasi yang jelas mengenai apa yang memuaskan dan apa yang kurang memuaskan. Informasi tersebut selanjutnya akan dipergunakan sebagai pijakan untuk menentukan kebijakan pengembangan yang bertumpu pada kepuasan wisatawan.

Secara umum penelitian ini bertujuan untuk menganalisis faktor-faktor yang mempengaruhi kepuasan wisatawan, menganalisis hubungan antara tingkat kepentingan wisatawan dan kinerja Daya Tarik Wisata, dan merancang strategi pengembangan berdasarkan kepuasan wisatawan terhadap kinerja elemen Daya Tarik Wisata Pantai Kuta Lombok

\section{Teori dan Metode}

Penelitian ini menggunakan teori elemen destinasi wisata dan teori perilaku konsumen, sedangkan konsep yang digunakan yaitu kepuasan wisatawan dan Daya Tarik Wisata. Mill dan Morrison (2009) menyebutkan lima elemen destinasi pariwisata yaitu attraction, facilities, infrastructure, transportation, dan hospitality yang 
disingkat dengan AFITH. Keberadaan elemen-elemen destinasi wisata tersebut bertujuan untuk memberi kepuasan penggalaman berwisata kepada wisatawan.

Segala sesuatu yang bisa disaksikan atau dinikmati oleh wisatawan pada sebuah destinasi wisata dinamakan sebagai atraksi (attraction). Karakteristik sebuah atraksi bisa berupa pemandangan alam seperti pantai, air terjun, gunung, hutan dan lainnya, cuaca dan iklim, budaya, sejarah. Fasilitas pariwisata dibutuhkan untuk menunjang kegiatan wisatawan di destinasi wisata yang dikunjungi. Kurangnya fasilitas wisata pada sebuah destinasi wisata menyebabkan ketidakpuasan wisatawan yang bisa berdampak pada citra destinasi (Mill dan Morrison, 2009). Untuk memenuhi kebutuhan wisatawan, selain atraksi dan fasilitas juga dibutuhkan ketersediaan infrastruktur. Mill dan Morrison (2009) mengemukakan infrastruktur terdiri dari konstruksi pembangunan bawah tanah dan permukaan tanah sebuah wilayah seperti sistem air, jaringan komunikasi, fasilitas kesehatan, sumber listrik atau energi, saluran drainase, jalan raya, dan juga sistem keamanan. Khadroo dan Seetanah (dalam Mill dan Morrison, 2009) menyatakan bahwa transportasi pada sebuah destinasi wisata memiliki kontribusi yang positif terhadap jumlah kunjungan wisatawan. Elemen destinasi wisata lainnya yang penting yaitu hospitality atau keramahtamahan yang terkait dengan keramahtamahan karyawan restoran, senyum oleh pegawai hotel dan juga keramahtamahan penduduk setempat.

Perilaku konsumen berdasarkan pendapat Engel dalam Rangkuti (2002) merupakan tindakan yang terlibat secara langsung dalam memperoleh, mengonsumsi, dan menghabiskan produk dan jasa. Gerald Zaldman dan Melanie Wallendorf 1979 (dalam Dwiastuti dkk, 2012) menyatakan bahwa perilaku konsumen adalah hal-hal yang dilakukan, proses, serta hubungan sosial individu, kelompok, maupun organisasi dalam memperoleh, memakai produk sebagai akibat yang didasarkan atas pengalaman yang diperoleh dari produk yang ia konsumsi. 
Dwiastuti (2012) menyatakan bahwa sangat perlu untuk memahami perilaku konsumen karena bermanfaat bagi penentuan kebijakan di masa mendatang.

Mempelajari perilaku konsumen memiliki sejumlah manfaat sesuai yang dikemukakan oleh Mowen 1995 (dalam Dwiastuti, 2012) yaitu:

a. Memudahkan manajer mengambil keputusan.

b. Pengetahuan analisis konsumen dapat manambah pengetahuan peneliti khususnya di pemasaran.

c. Mempermudah penciptaan hukum dan peraturan mengenai pembelian dan penjualan jasa yang dilakukan oleh penentu kebijakan sebagai regulator dan legislator.

d. Bermanfaat bagi konsumen sebagai dasar menentukan keputusan pembelian.

Selain mempelajari manfaat yang diperoleh dari prilaku konsumen, hal yang perlu dipelajari lainnya yaitu model prilaku konsumen. Rangkuti (2002) menyatakan bahwa sebagian besar model prilaku konsumen bersumber dari model rangsangan tanggapan. Untuk lebih jelasnya perhatikan Gambar 2.1 berikut ini:

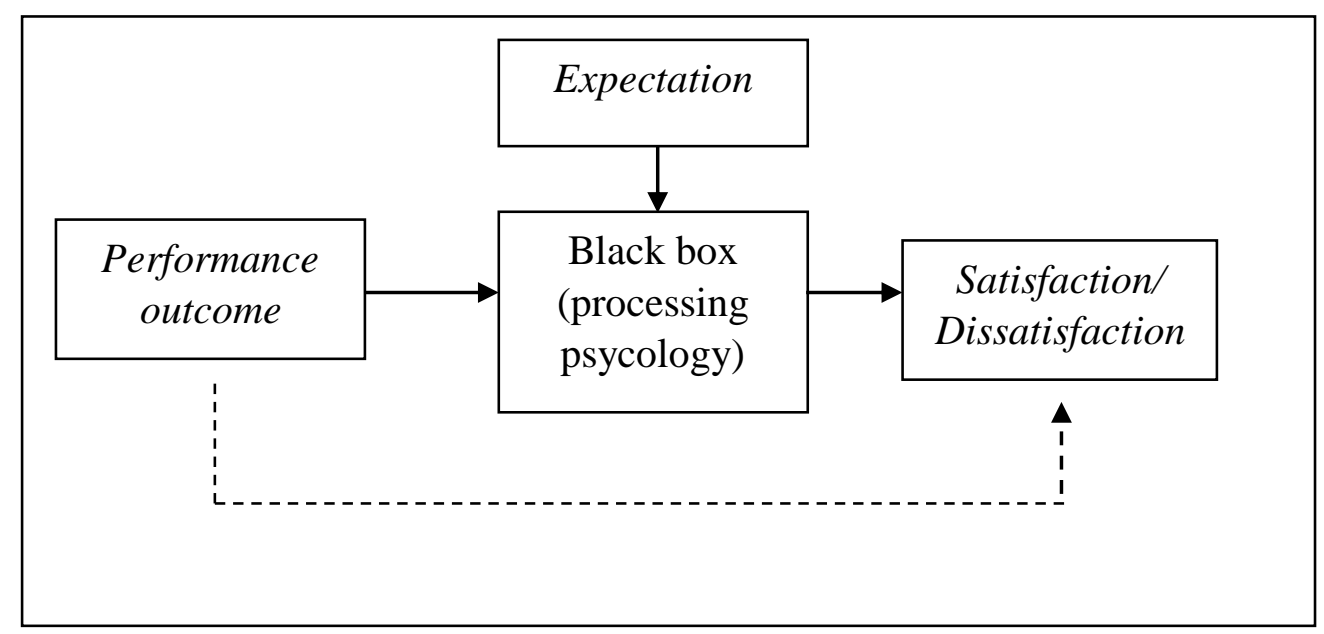

Gambar 2.1 Model Perilaku Konsumen 
Gambar 2.1 memperlihatkan tanggapan konsumen memiliki dua kemungkinan yaitu puas dan tidak puas tergantung dari harapan dan kinerja produk yang dikonsumsi. Tanggapan konsumen yang berupa kepuasan atau ketidakpuasan tersebut akan tercermin dari perilakunya. Kotler 2012 (dalam Suryadana dan Octavia, 2015) menyatakan bahwa konsumen yang terpuaskan oleh kinerja barang/jasa yang pakainya akan cenderung setia (loyal) terhadap produk yang sama, merekomendasikan produk yang sama kepada orang lain, menceritakan hal baik serta menjadikan perusahaan sebagai prioritas pilihan ketika melakukan pembelian lainnya. Hal sebaliknya akan terjadi apabila terdapat ketidakpuasan pelanggan. Tanggapan atas ketidapuasannya terhadap produk yang dikonsumsi akan tercermin dari perilakunya seperti tidak merekomendasikan produk tersebut ke pembeli lain, menceritakan hal negatif tentang produk dan perusahaan serta tidak menjadikan perusahaan sebagai dasar pertimbangan saat melakukan pembelian terhadap produk lain.

Kepuasan ialah respon atau pendapat konsumen mengenai sebuah produk atau layanan yang menyediakan tingkat kesenangan, apakah produk tersebut memenuhi, tidak memenuhi atau melebihi tingkat kesenangan konsumen (Oliver, 2010). Kotler dan Keller (2009) secara umum menyatakan bahwa kepuasan ialah perasaan senang atau kecewa seseorang terhadap perbandingan harapan dan kinerja sebuah produk. Hasan (2015) menyatakan kepuasan wisatawan ialah perasaan yang dirasakan oleh wisatawan setelah membandingkan harapan dengan kenyataan. Dimana ketika wisatawan merasakan kalau kinerja produk pariwisata pada destinasi yang mereka kunjungi lebih tinggi dari harapan, maka bisa dikatakan kalau mereka akan merasa puas. 
Terdapat tiga metode yang dapat digunakan untuk mengukur tingkat kepuasan konsumen menurut Kotler dan Keller (2009: 166) yaitu sebagai berikut:
a. Periodic surveys (survey berkala).
b. Customer lost rate (tingkat kehilangan pelanggan).
c. Mystery shoppers (pelanggan misterius).

Kotler (2002) menambahkan satu metode pengukuran kepuasan konsumen yaitu menggunakan sistem keluhan dan saran. Sistem ini memungkinkan konsumen untuk memberi saran, keluhan, serta pendapat menggunakan media seperti kotak saran, telpon dan SMS gratis, email. Keluhan dan saran yang disampaikan konsumen tersebut diharapkan dapat menjadi masukan bagi perusahaan untuk mengatasi permasalahan terkait hal yang menjadi keluhan. Pengukuran kepuasan konsumen bertujuan untuk mengidentifikasi keperluan, tingkat kepuasan yang dirasa penting dari kinerja perusahaan, perbandingan kepuasan terhadap perusahaan yang satu dan lainnya, melakukan identifikasi prioritas peningkatan, dan melakukan pengukuran indeks kepuasan konsumen sebagai dasar pemantauan perkembangan.

Hasan (2015: 371-373) menyebutkan kepuasan wisatawan dipengaruhi oleh sejumlah faktor ketika berwisata ke sebuah destinasi yaitu keramahtamahan masyarakat setempat serta sikap yang ditunjukkan pegawai, kualitas layanan, tanggapan terhadap keluhan wisatawan, fasilitas dan akomodasi, serta harga.

Konsep Daya Tarik Wisata dalam Undang-undang Republik Indonesia No. 10 Tahun 2009 tentang kepariwisataan, didefinisikan sebagai segala keunikan, keindahan, dan nilai berupa keanekaragaman kekayaan alam, budaya, dan hasil buatan manusia yang menjadi sasaran atau tujuan kunjungan wisatawan. Mill dan Morrison (2009) menyatakan bahwa atraksi wisata di sebuah destinasi dapat menarik minat wisatawan untuk mengunjungi tempat tersebut. Setiap destinasi 
wisata memiliki keunikan yang berbeda-beda. Terdapat dua jenis daya tarik wisata menurut Suryadana dan Octavia (2015) yaitu daya tarik wisata alam dan daya tarik wisata budaya. Pantai Kuta Lombok memiliki daya tarik berupa keunikan garis pantai indah dengan butiran pasir putih menyerupai biji merica.

Metode penelitian yang digunakan yaitu metode penelitian kuantitatif yang didukung dengan pendekatan kualitatif. Populasi dalam penelitian ini ialah wisatawan mancanegara yang berusia 18 tahun ke atas, pernah berkunjung minimal satu kali ke Pantai Kuta Lombok, datang dengan tujuan untuk berlibur, dan tinggal di akomodasi yang berada di area Pantai Kuta Lombok. Ukuran sampel yang digunakan sebanyak 165 dan 30. Instrumen penelitian yang digunakan untuk mengumpulkan data mengenai kepuasan wisatawan ialah kuesioner dengan skala likert 1-5. Analisis data menggunakan analisis faktor, Important Performance Analysis, dan analisis deskriptif.

\section{Hasil dan Pembahasan}

\section{Gambaran Umum Pantai Kuta Lombok}

Pantai Kuta Lombok merupakan salah satu pantai di Pulau Lombok yang terletak di Desa Kuta Kecamatan Pujut Kabupaten Lombok Tengah. Pantai Kuta Lombok termasuk ke dalam Kawasan Ekonomi Khusus Mandalika. Untuk mencapai Pantai Kuta Lombok dibutuhkan waktu selama 20 menit dari bandar udara internasional Lombok menggunakan kendaraan sepeda motor, mobi, ataupun bus. Berbagai kegiatan yang bisa dilakukan wisatawan selama mengunjungi Pantai Kuta Lombok seperti bermain kano, memancing, paragliding, dan juga sunbathing.

Sebagai bagian dari Kawasan Ekonomi Khusus Mandalika, Pantai Kuta Lombok dikelola oleh ITDC (Indonesia Tourism Development Corporation). Sebagai Daya Tarik Wisata yang terletak di jantung Kawasan Ekonomi Khusus Mandalika, berbagai pembangunanpun sudah dilakukan seperti pembangunan hotel-hotel 
berbintang dan masjid, penataan Pantai Kuta, pembangunan fasilitas pariwisata di area pantai berupa pusat informasi, pusat pelayanan kesehatan, toilet umum, dan juga fasilitas bermain untuk anak, perbaikan infrastruktur jalan, dan juga akan dibuat sirkuit untuk moto GP.

\section{Karakteristik Responden}

Responden dalam penelitian ini ialah wisatawan mancanegara. Adapun karakteristik responden dibedakan berdasarkan benua asal, umur, jenis kelamin, pendidikan terakhir, pekerjaan, lama tinggal, jenis akomodasi, tujuan, dan jumlah kunjungan ke Pantai Kuta Lombok.

Dilihat dari asal benua, responden terbanyak dalam penelitian ini berasal dari Benua Eropa sebanyak 122 orang (73,9\%). Dilihat dari rentan usia, responden dengan jumlah terbanyak ialah wisatawan mancanegara berusia produktif dengan rentan usia 25-44 tahun sebanyak 92 orang (55,8\%). Dilihat dari jenis kelamin, tidak terdapat perbedaan jumlah signifikan diantara responden laki-laki dan responden perempuan yang mengunjungi Daya Tarik wisata Pantai Kuta Lombok, dimana sebanyak 86 (52,11\%) responden laki-laki dan sisanya 79 (47,9\%) merupakan responden perempuan. Berdasarkan pendidikan terakhirnya, responden tergolong berpendidikan tinggi yaitu sebanyak sebanyak 39 (23,6\%) orang merupakan tamatan college, $47(28,6 \%)$ orang merupakan tamatan S1, 40 (24,2\%) orang merupakan tamatan S2. Responden dengan pekerjaan sebagai karyawan merupakan responden terbanyak pada penelitian ini dengan jumlah sebayak 66 (40\%) orang. Berdasarkan lama tinggal, responden dalam penelitian ini sebanyak 88 (53,3\%) orang memiliki lama tinggal 1-7 hari. Berdasarkan jenis akomodasi tempat menginap, responden dalam penelitian ini menginap di berbagai jenis akomodasi seperti homestay, hotel, bungalow, villa, hostel dan rumah penduduk setempat yang disewakan. Homestay merupakan jenis akomodasi yang paling banyak dipilih oleh responden sebagai tempat tinggal dibandingkan jenis akomodasi lainnya yaitu sebanyak sebanyak 70 
$(42,2 \%)$ orang. Seluruh responden berkunjung dengan tujuan untuk berlibur. Berdasarkan jumlah kunjungan, sebagian besar responden berkunjung untuk yang pertama kalinya yaitu sebanyak $128(77,6 \%)$ orang.

\section{Faktor yang Mempengaruhi Kepuasan Wisatawan Berkunjung Pantai Kuta Lombok}

Analisis faktor yang sudah dilakukan menunjukkan kepuasan wisatawan mancanegara yang berkunjung ke Pantai Kuta Lombok dipengaruhi oleh delapan faktor. Hasil analisis disajikan pada Tabel 3.1.

Tabel 3.1 Faktor-faktor yang Mempengaruhi Kepuasan Wisatawan

\begin{tabular}{|c|c|c|c|}
\hline $\begin{array}{c}\text { Indikator } \\
\text { (1) }\end{array}$ & $\begin{array}{c}\text { Faktor loading } \\
\text { (2) }\end{array}$ & $\begin{array}{l}\text { Faktor } \\
(3)\end{array}$ & $\begin{array}{c}\% \text { varians } \\
(4)\end{array}$ \\
\hline Kenyamanan akomodasi & 0,798 & \multirow{6}{*}{ Akomodasi } & \multirow{6}{*}{26,606} \\
\hline Kualitas pelayanan akomodasi & 0,729 & & \\
\hline Fasilitas akomodasi & 0,685 & & \\
\hline Kebersihan akomodasi & 0,647 & & \\
\hline Kualitas makanan akomodasi & 0,615 & & \\
\hline Ketersediaan pusat informasi & 0,525 & & \\
\hline Hospitality karyawan tempat makan & 0,772 & \multirow{5}{*}{ Hospitality } & \multirow{5}{*}{7,967} \\
\hline Hospitality karyawan akomodasi & 0,718 & & \\
\hline Sikap masyarakat lokal & 0,665 & & \\
\hline Iklim tropis & 0,574 & & \\
\hline Harga akomodasi & 0,555 & & \\
\hline Ketersediaan kendaraan disewa & 0,769 & \multirow[t]{3}{*}{ Transportasi } & \multirow[t]{3}{*}{5,343} \\
\hline Jarak dari airport & 0,665 & & \\
\hline Kualitas kendaraan disewa & 0,637 & & \\
\hline Ketersediaan toilet umum & 0,691 & \multirow{3}{*}{$\begin{array}{c}\text { Fasilitas } \\
\text { umum }\end{array}$} & \multirow{3}{*}{5,161} \\
\hline Kemudahan akses transportasi umum & 0,660 & & \\
\hline Kebersihan DTW & 0,563 & & \\
\hline Kualitas jalan & 0,733 & \multirow{4}{*}{ Infrastruktur } & \multirow{4}{*}{4,508} \\
\hline Kualitas signal & 0,611 & & \\
\hline Keamanan ketika berkendara & 0,538 & & \\
\hline Ketersediaan penanda jalan & 0,517 & & \\
\hline Ketersediaan toko souvenir & 0,690 & \multirow{3}{*}{$\begin{array}{c}\text { Fasilitas } \\
\text { wisata }\end{array}$} & \multirow{3}{*}{4,280} \\
\hline Ketersediaan fasilitas bermain anak & 0,628 & & \\
\hline Ketersediaan tempat makan & 0,590 & & \\
\hline Sikap pedagang souvenir & 0,670 & \multirow{2}{*}{ Keamanan } & \multirow{2}{*}{3,523} \\
\hline Keamanan di DTW & 0,519 & & \\
\hline Harga sewa kendaraan & 0,635 & \multirow{2}{*}{ Harga } & \multirow{2}{*}{3,294} \\
\hline Harga makanan dan minuman & 0,584 & & \\
\hline Total & & & 60,682 \\
\hline
\end{tabular}

Sumber: Hasil penelitian, 2019 
Faktor pertama yang mempengaruhi kepuasan wisatawan mancanegara yang mengunjungi Pantai Kuta Lombok dinamakan faktor akomodasi. Persentase varians dari faktor akomodasi ini sebesar $26,606 \%$ dan merupakan faktor dengan varians terbesar. Terdapat enam indikator yang termasuk ke dalam faktor akomodasi yaitu kebersihan akomodasi, kualitas makanan dan minuman di akomodasi, kualitas pelayanan akomodasi, kenyamanan akomodasi, fasilitas akomodasi dan ketersediaan pusat informasi.

Faktor hospitality ialah faktor kedua yang mempengaruhi kepuasan wisatawan mancanegara yang sudah mengunjungi Pantai Kuta Lombok dengan besar varians 7,967\%. Hospitality terkait dengan sikap maupun tata cara memperlakukan wisatawan mancanegara selama berada di tempat wisata. Faktor hospitality ini terdiri dari lima indikator yaitu hospitality karyawan tempat makan, hospitality karyawan akomodasi, sikap penduduk lokal, iklim tropis dan harga akomodasi.

Faktor ketiga yang memepengaruhi kepuasan wisatawan mancanegara dinamakan sebagai faktor transportasi. Faktor ini memiliki nilai varians sebesar 5,343\%. Adapun indikator yang termasuk ke dalam faktor transporatasi sebanyak tiga buah indikator yaitu ketersediaan kendaraan yang disewa, jarak dari airport/pelabuhan ke Pantai Kuta Lombok, dan kualitas kendaraan yang disewa.

Faktor keempat yang mempengaruhi kepuasan wisatawan dinamakan sebagai faktor fasilitas umum. Faktor fasilitas umum ini mempunyai nilai varians sebesar 5,161\%. Indikator-indikator pada faktor ini terdiri dari tiga buah indikator yaitu ketersediaan toilet umum, kebersihan pantai, dan kemudahan akses transportasi umum.

Faktor infrastruktur merupakan faktor ke lima yang yang mempengaruhi kepuasan wisatawan mancanegara yang berkunjung ke Daya Tarik Wisata Pantai Kuta Lombok. Nilai varians faktor infrastruktur ini sebesar 4,508\%. Terdapat 
sebanyak empat indikator yang termasuk ke dalam faktor ini yaitu kualitas jalan, kualitas jaringan komunikasi, keamanan ketika berkendara dan ketersediaan penanda jalan.

Faktor ke enam yang memepengaruhi kepuasan wisatawan mancanegara dinamakan sebagai faktor fasilitas pariwisata. Nilai varians dari faktor ini sebesar 4,280\%. Faktor fasilitas pariwisata ini terdiri dari tiga indikator yaitu yaitu ketersediaan toko oleh-oleh, ketersediaan fasilitas bermain anak dan ketersediaan tempat makan.

Faktor ke tujuh yang mempengaruhi kepuasan wisatawan mancanegara dalam kunjungannya ke Pantai Kuta Lombok dinamakan faktor keamanan. Persentase nilai varians dari faktor keamanan ini sebesar 3,523\%. Adapun indikatorindikator yang termasuk dalam faktor ini yaitu sikap pedagang souvenir dan kemanan.

Faktor harga merupakan faktor ke delapan yang mempengaruhi kepuasan wisatawan mancanegara yang berkunjung ke Pantai Kuta Lombok. Faktor ini memiliki persentase nilai varians terkecil diantara faktor-faktor lainnya yakni sebesar 3,294\%. Terdapat dua indikator yang termasuk ke dalam faktor harga ini yaitu harga sewa kendaraan dan harga makanan dan minuman.

\section{Hubungan Antara Tingkat Kepentingan Wisatawan dan Kinerja Daya Tarik Wisata Pantai Kuta Lombok}

Analisis IPA (Important Performance Analysis) digunakan untuk mengetahui hubungan antara tingkat kepentingan wisatawan dan kinerja Daya Tarik Wisata Pantai Kuta Lombok. Berdasarkan analisis yang sudah dilakukan terhadap hasil pengisian kuesioner oleh wisatawan mancanegara, secara umum dapat dikatakan bahwa kinerja dari elemen Daya Tarik Wisata Pantai Kuta Lombok sudah tergolong baik dengan nilai rata-rata sebesar 3,81 yang sudah melebihi harapan dari wisatawan. Untuk lebih jelasnya perhatikan Tabel 3.2. 
Tabel 3.2 Rata-Rata Tingkat Kepentingan Dan Tingkat Kinerja Keseluruhan Elemen Daya Tarik Wisata Pantai Kuta Lombok

\begin{tabular}{|c|c|c|}
\hline $\begin{array}{c}\text { Elemen } \\
(1)\end{array}$ & $\begin{array}{c}\text { Performance } \\
\text { (Xi) } \\
(2) \\
\end{array}$ & $\begin{array}{c}\text { Important } \\
\text { (Yi) } \\
(3)\end{array}$ \\
\hline Ketersediaan pusat informasi & 3,4 & 3,4 \\
\hline Kebersihan akomodasi & 4,03 & 4,03 \\
\hline Kualitas makanan dan minuman di akomodasi & 4,33 & 3,8 \\
\hline Kualitas pelayanan akomodasi & 4,46 & 4,06 \\
\hline Kenyamanan akomodasi & 4,46 & 4,03 \\
\hline Fasilitas akomodasi & 3,96 & 3,7 \\
\hline Iklim tropis & 4,5 & 4,26 \\
\hline Sikap penduduk lokal & 4,43 & 3,83 \\
\hline Hospitality pegawai akomodasi & 4,56 & 4 \\
\hline Hospitality pegawai tempat makan & 4,63 & 4,06 \\
\hline Harga akomodasi & 4,1 & 4,03 \\
\hline Jarak dari bandara/pelabuhan & 3,7 & 3,76 \\
\hline Ketersediaan kendaraan yang disewa & 4,3 & 4,2 \\
\hline Kualitas kendaraan yang disewa & 3,83 & 3,86 \\
\hline Kebersihan pantai & 3,03 & 3,4 \\
\hline Ketersediaan kamar mandi umum & 2,6 & 3,1 \\
\hline Kemudahan akses transportasi umum & 2,4 & 2,9 \\
\hline Kualitas jaringan komunikasi & 3,4 & 3,5 \\
\hline Kualitas jalan & 3,66 & 3,1 \\
\hline Ketersediaan penanda jalan & 3,53 & 3,3 \\
\hline Keselamatan saat berkendara & 3,56 & 3,43 \\
\hline Ketersediaan toko oleh-oleh & 3,8 & 3,9 \\
\hline Ketersediaan tempat makan & 4,46 & 4,06 \\
\hline Ketersediaan fasilitas rekreasi untuk anak & 3,2 & 3,13 \\
\hline Keamanan di pantai & 4,06 & 3,66 \\
\hline Sikap pedagang oleh-oleh keliling & 2,66 & 3,26 \\
\hline Harga kendaraan yang disewa & 3,7 & 3,46 \\
\hline Harga makanan dan minuman & 4,06 & 3,66 \\
\hline TOTAL & 3,81 & 3,67 \\
\hline
\end{tabular}

Sumber: Hasil penelitian, 2019

Kinerja yang baik dari elemen-elemen Daya Tarik Wisata Pantai Kuta Lombok ini juga dapat dilihat dari tingkat kesesuaian kepentingan dan tingkat kinerjanya. Adapun hasil penghitungan tingkat kesesuaian kepentingan dan kinerja 
elemen-elemen Daya Tarik Wisata Pantai Kuta Lombok sebesar 107,43\%. Hasil tersebut menunjukkan bahwa nilai Tki $\geq 100 \%$ yang artinya kinerja elemen-elemen Daya Tarik Wisata Pantai Kuta Lombok sudah memuaskan wisatawan mancanegara yang berkunjung. Hasil pengitungan disajikan pada Tabel 3.3.

Tabel 3.3 Tingkat Kesesuaian Kepentingan dan Kinerja Elemen Daya Tarik Wisata Pantai Kuta Lombok

\begin{tabular}{|c|c|c|c|}
\hline $\begin{array}{c}\text { Item } \\
(1)\end{array}$ & $\begin{array}{c}\text { Performance } \\
\text { (Xi) } \\
(2)\end{array}$ & $\begin{array}{c}\text { Importance } \\
\text { (Yi) } \\
(3)\end{array}$ & $\begin{array}{c}\text { Tingkat } \\
\text { kesesuaian } \\
\text { (Tki) (\%) } \\
(4)\end{array}$ \\
\hline Ketersediaan pusat informasi & 102 & 102 & 100 \\
\hline Kebersihan akomodasi & 121 & 121 & 100 \\
\hline $\begin{array}{l}\text { Kualitas makanan dan minuman di } \\
\text { akomodasi }\end{array}$ & 130 & 114 & 114,03 \\
\hline Kualitas pelayanan akomodasi & 134 & 122 & 109,83 \\
\hline Kenyamanan akomodasi & 134 & 121 & 110,74 \\
\hline Fasilitas akomodasi & 119 & 111 & 107,20 \\
\hline Iklim tropis & 135 & 128 & 105,46 \\
\hline Sikap penduduk lokal & 133 & 115 & 115,65 \\
\hline Hospitality pegawai akomodasi & 137 & 120 & 114,16 \\
\hline Hospitality pegawai tempat makan & 139 & 122 & 113,93 \\
\hline Harga akomodasi & 123 & 121 & 101,65 \\
\hline Jarak dari bandara/pelabuhan & 111 & 113 & 98,23 \\
\hline Ketersediaan kendaraan yang disewa & 129 & 126 & 102,23 \\
\hline Kualitas kendaraan yang disewa & 115 & 116 & 99,13 \\
\hline Kebersihan pantai & 91 & 102 & 89,21 \\
\hline Ketersediaan kamar mandi umum & 78 & 93 & 83,87 \\
\hline Kemudahan akses transportasi umum & 72 & 87 & 82,75 \\
\hline Kualitas jaringan komunikasi & 102 & 105 & 97,14 \\
\hline Kualitas jalan & 110 & 99 & 111,11 \\
\hline Ketersediaan penanda jalan & 106 & 99 & 107,07 \\
\hline Keselamatan saat berkendara & 107 & 103 & 103,38 \\
\hline Ketersediaan toko oleh-oleh & 114 & 117 & 97,43 \\
\hline Ketersediaan tempat makan & 134 & 122 & 109,83 \\
\hline Ketersediaan fasilitas rekreasi untuk anak & 96 & 94 & 102,12 \\
\hline Keamanan di pantai & 122 & 110 & 110,90 \\
\hline Sikap pedagang oleh-oleh keliling & 80 & 98 & 81,16 \\
\hline Harga kendaraan yang disewa & 111 & 104 & 106,73 \\
\hline Harga makanan dan minuman & 122 & 110 & 110,90 \\
\hline TOTAL & 3207 & 2985 & 107,43 \\
\hline
\end{tabular}

Sumber: Data primer dan diolah, 2019 


\section{Prioritas Pengembangan Pantai Kuta Lombok}

Strategi pengembangan didasarkan atas tingkat kepuasan wisatawan mancanegara terhadap kinerja elemen Daya Tarik Wisata Pantai Kuta Lombok yang sudah dianalisis menggunakan analisis IPA (Important Performance Analysis). Nilai rata-rata tingkat kepentingan serta tingkat kinerja keseluruhan elemen Daya Tarik Wisata Pantai Kuta Lombok digunakan sebagai dasar pembuatan matrik diagram kartesius pada analsis IPA (Important Performance Analysis).

Tujuan pembuatan diagram kartesius ini ialah untuk menentukan skala prioritas perbaikan kinerja elemen Pantai Kuta Lombok yang dibagi ke dalam empat kuadran. Adapun nilai rata-rata tingkat kepentingan dan tingkat kinerja keseluruhan elemen Pantai Kuta Lombok disajikan pada Tabel 3.2. Nilai rata-rata tingkat kinerja(performnance) keseluruhan elemen ialah 3,81 dan nilai rata-rata tingkat kepentingan (important) keseluruhan elemen ialah 3,67. Perhatikan Gambar 3.1.

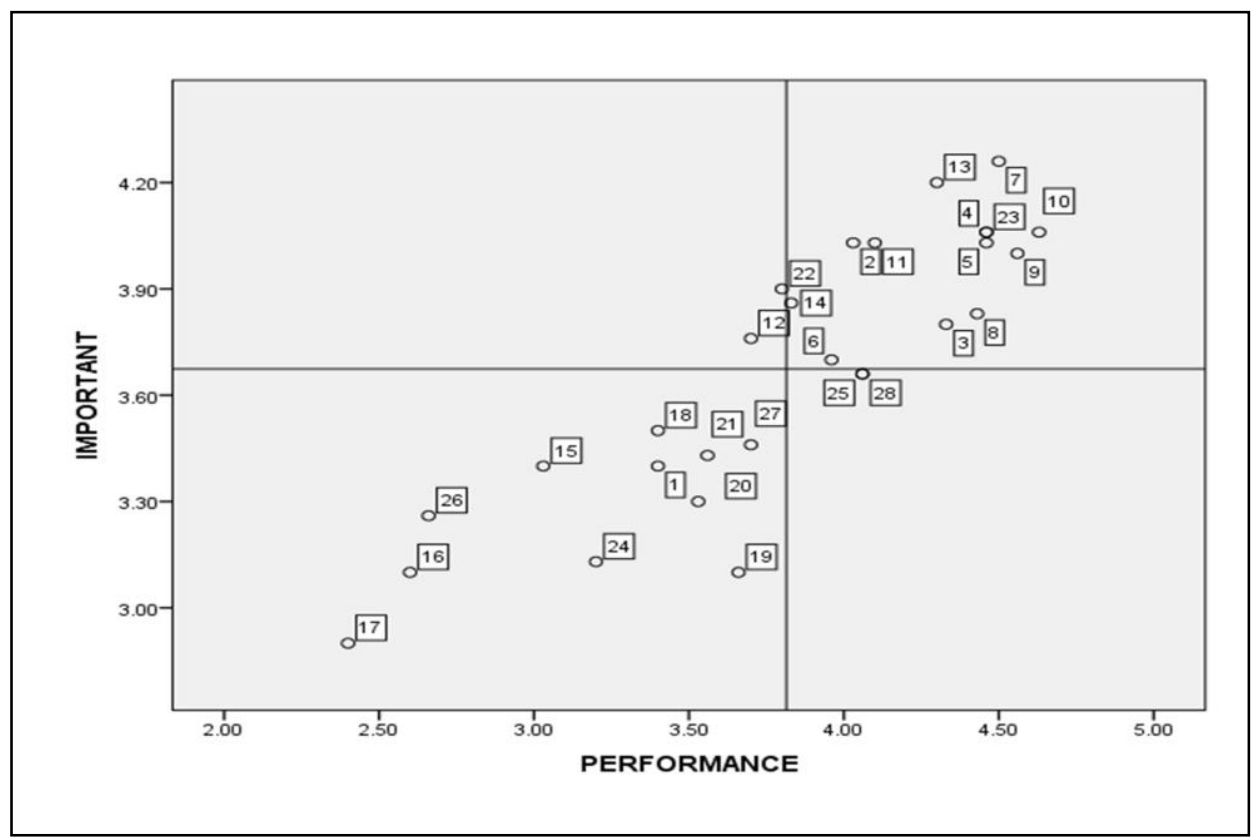

Gambar 3.1 Diagram Kartesius 
Berdasarkan Gambar 3.1 dapat dilihat indikator yang mempengaruhi kepuasan wisatawan berkunjung ke Pantai Kuta Lombok terbagi ke dalam empat kuadran. Penjabaran mengenai masing-masing kuadran akan dijelaskan sebagai berikut.

\section{a. Kuadran I}

Wilayah ini merupakan wilayah yang menunjukkan indikator-indikator elemen Daya Tarik Wisata Pantai Kuta Lombok yang penting bagi wisatawan, namun kinerjanya belum sesuai harapan sehingga membuat wisatawan menjadi tidak puas. Adapun indikator pada kuadran I yaitu jarak dari bandara/pelabuhan ke pantai kuta lombok dan ketersediaan toko oleh-oleh.

\section{b. Kuadran II}

Indikator-indikator pada kuadran ini dirasa penting oleh wisatawan dan sudah memiliki kinerja yang memuaskan. Terdapat sebanyak 13 indikator pada kuadran ini yang memiliki kinerja bagus dan memuaskan wisatawan yaitu kebersihan akomodasi, kualitas makanan dan minuman di akomodasi, kualitas pelayanan di akomodasi, kenyamanan di akomodasi, fasilitas akomodasi, iklim tropis, sikap penduduk lokal, hospitality karyawan akomodasi, hospitality karyawan tempat makan, harga akomodasi, ketersediaan kendaraan yang disewa, kualitas kendaraan yang disewa, dan ketersediaan tempat makan.

\section{c. Kuadran III}

Indikator-indikator yang kurang dianggap penting oleh wisatawan berada pada kuadran ini dan juga pada kenyataannya kinerja dari indikator pada kuadran ini memang tidak begitu baik. Indikator-indikator pada kuadran ini memiliki pengaruh relatif rendah terhadap kepuasan wisatawan. Indikator pada kuadran ini sebanyak 11 yaitu adanya pusat informasi, kebersihan pantai, adanya kamar mandi umum, kemudahan akses transportasi umum, kualitas jaringan komunikasi (internet), 
kualitas jalan, adanya penanda jalan, keamanan ketika berkendara, fasilitas rekreasi untuk anak, sikap pedagang oleh-oleh, harga sewa kendaraan.

\section{d. Kuadran IV}

Indikator-indikator Daya Tarik Wisata Pantai Kuta Lombok yang berada pada kuadra ini kurang begitu penting bagi wisatawan, akan tetapi kinerjanya sudah sangat baik dan terkesan berlebihan. Kinerja indikator-indikator pada kuadran ini bisa dikurangi. Pada kuadran ini terdapat dua buah indikator yaitu keamanan serta harga makanan dan minuman di area Pantai Kuta Lombok.

Penentuan prioritas pengembangan Pantai Kuta Lombok dilakukan berdasarkan hasil matrik diagram kartesius Important Performance Analysis. Berdasarkan hasil analisis matrik diagram kartesius (Gambar 3.1), strategi pengembangan yang perlu dilakukan untuk meningkatkan kepuasan wisatawan mancanegara yaitu segera meningkatkan kinerja indikator-indiator yanga berada pada kuadran I, mempertahankan kinerja indikator-indikator pada kuadran II serta mengurangi kinerja indikator-indikator pada kuadran IV.

\section{Penutup}

Berdasarkan hasil analisis serta pembahasan pada penelitian ini, kepuasan wisatawan mancanegara berkunjung ke Pantai Kuta Lombok dipengaruhi oleh delapan faktor yaitu faktor akomodasi, hospitality, transportasi, fasilitas umum, infrastruktur, fasilitas pariwisata, keamanan, dan harga. Hasil analisis IPA (Important Performance Analysis) menunjukkan bahwa kinerja elemen-elemen Daya Tarik Wisata Pantai Kuta Lombok sudah dapat memuaskan wisatawan

Strategi pengembangan Pantai Kuta Lombok yaitu segera meningkatkan kinerja elemen-elemen Daya Tarik Wisata yang berada pada kuadran I sebagai prioritas utama pengembangan, mempertahankan kinerja elemen-elemen pada kuadran II 
yang merupakan kekuatan Daya Tarik Wisata, memperbaiki kinerja elemen-elemen pada kuadran III dan mengurangi kinerja elemen-elemen pada kuadran IV.

\section{Ucapan Terimakasih}

Pada kesempatan ini penulis menyampaikan ucapan terimaksih yang sebesarbesarnya kepada Dr. Ir. I Gusti Ayu Oka Suryawardani, M.Mgt., Ph.D selaku Koordinator Program Studi Magister Pariwisata dan juga sebagai Pembimbing I serta Dr. I Ketut Surya Diarta, S.P., M.A selaku Pembimbing II. Ucapan terima kasih juga penulis sampaikan kepada para penguji yaitu Prof. Dr. I Nyoman Darma Putra, M.Litt., Dr. I Putu Gde Sukaatmadja, SE.,MP dan Dr. I Wayan Suardana SST.Par., M. Par. Atas saran dan bimbingannya. Ucapan yang sama juga diucapkan kepada Rektor Universitas Udayana, Prof. Dr. A.A. Raka Sudewi, Sp. S (K), Dr. Drs. I Nyoman Sunarta, M. Si selaku Dekan Fakultas Pariwisata Universitas Udayana yang telah memberikan kesempatan, fasilitas serta bantuan selama perkuliahan.

\section{Daftar Pustaka}

Aktas, A., Aydin Cevirgen dan Boran Toker. 2009. "Assessing Holiday Satisfaction Of German And Russian Tourists Visiting Alanya." Journal of Tourism and Hospitality Management, Vol.15, No.1, hlmn. 1-12.

Beritagar. 2018. "Mewujudkan Mimpi Wisata Berkelas di KEK Mandalika”, sumber: https://beritagar.id/artikel/piknik/mewujudkan-mimpi-wisata-berkelas-di-kekmandalika. Diakses 11/02/2019.

Corte, V.D., Mauro Sciarelli, Clelia Cacella dan Giovanna Del Gaudio. 2015. "Customer Satisfaction in Tourist Destination: The Case of Tourism Offer in The City of Naples." Journal of Investment and Management, Vol. 4, No. 1-1, hlmn. 39-50.

Dwiastuti, R., Agustina Shinta dan Riyanti Isaskar. 2012. Ilmu Prilaku Konsumen. Malang: Universitas Brawijaya Press. 
Hasan, A. 2015. Tourism Marketing. Yogyakarta: Center for Acadenic Publishing Service.

Kotler, P. dan Kevin L. Keller. 2009. Marketing Management 13th Edition. New Jersey: Pearson Education.

2002. Manajemen Pemasaran Edisi Milenium. Jakarta: Pearson Education Asia Pte. Ltd. Dan PT. Prenhallindo.

Mill, R.C. dan Alastair M. Morrison. 2009. The Tourism System. United States of America: Kendall Hunt Publishing Company.

Oliver, R. L. 2010. Satisfaction: A Behavioral Perspective on The Consumer. New York: Routledge.

Peraturan Daerah Provinsi Nusa Tenggara Barat Nomor 7 Tahun 2013 Tentang Rencana Induk Pembangunan Kepariwisataan Daerah Tahun 2013-2028.

Rangkuti, F. 2002. Measuring Consumer Satisfaction. Jakarta: Gramedia Pustaka Utama.

Saufi, A., Frans Teguh, Hari Ristanto, Prayitno Basuki, Oliver Oehms, Dian Vitriani, Sybille Creutz, dan Baiq Hulum Nuzully. 2015. Rencana Induk Pariwisata Berkelanjutan Pulau Lombok Tahun 2015-2019. Mataram: Badan Perencanaan dan Pembanguna Daerah Provinsi NTB.

Suara NTB. 2017. “Jokowi: Toilet di KEK Mandalika Harus Berstadar International",sumber:https://www.suarantb.com/headline/2017/10/247324/Jok owi.Toilet.di.KEK.Mandalika.Harus.Berstandar.Internasional/. Diakses 11/02/2019.

Suryadana, M. L. dan Vanny Octavia. 2015. Pengantar Pemasaran Pariwisata. Bandung: Alfabeta.

Tripadvisor. 2018. “Traveler Rating", sumber: https://www.tripadvisor.com/Attraction_Review-g297733-d1036419-ReviewsKuta_Beach_Lombok-Lombok_West_Nusa_Tenggara.html\#REVIEWS. Diakses $11 / 02 / 2019$.

Wang, Y. 2016. More Important Than Ever: Measuring Tourist Satisfaction. Queensland: Griffith University.

Undang-undang Republik Indonesia No. 10 Tahun 2009 Tentang Kepariwisataan. 


\section{Profil Penulis}

Yuni Sulpia Hariani lahir di Murbaya Lombok pada 11 Juni 1988. Ia menyelesaikan pendidikan S1 Pendidikan Bahasa Inggris di FKIP Universitas Mataram pada tahun 2012 dan Program magister pariwisata di Universitas Udayana pada tahun 2019. Penulis merupakan pemilik trekking organizer bernama Lombok Plus+ yang juga menyewakan trekking equipments, cooking class, serta aktif mengelola kegiatan Voluntourism yang mengatur kegiatan berwisata dan kegiatan mengajar Bahasa Inggris di daerah pedesaan oleh wisatawan mancanegara di Pulau Lombok. Saat ini penulis menjabat sebagai manager promosi dan pemasaran di Badan Promosi Pariwisata Daerah Kabupaten Lombok Tengah NTB.

Dr. Ir. I Gusti Ayu Oka Suryawardani, M.Mgt., Ph.D merupakan Dosen yang saat ini menjabat sebagai Ketua Program Studi Magister Pariwisata yang menyelesaikan pendidikan S1 di Fakultas Pertanian Universitas Udayana, S2 di Faculty of Economic Business and Law, The University of Queensland, Brisbane Autsralia dan S3 Double Degree Indonesia Prancis: Unud - Paris 1 Pantheon Sorbonne, Paris, France. Bidang keahlian yang ditekuni adalah Consumen Behaviour, Tourism Economics and Tourism Marketing dan Permodelan Sistem Pariwisata. 